\title{
'TINKER' FOX AND THE POLITICS OF GARRISON WARFARE IN THE WEST MIDLANDS, 1643-50
}

\author{
By ANDREW HOPPER \\ aniversity of gork
}

The identity of the axeman who severed Charles I's head from his body on 30 Janury 1649 has been a constant source of speculation. No convincing explanation has ever been offered and none is likely now to be found. But one of the earliest and most persistent is the one recorded by the earl of Leicester in his diary for the 30 January 1649 itself: 'The executioners were two and disguised in saylor's clothes with visards and peruques, unknown yet. Some have a conceit that he that gave the stroke was a Colonel Foxe, and the other Captaine Joyce who tooke the King from Holmby, but that is not believed'. Given their overwhelming urge to express condemnation of the regicide, some royalist gentlemen were less sceptical; a letter received by Joseph Kent in Venice providing details of the king's execution recounted: 'A Colonel, formerly a brazier [i.e. Fox] to the great dishonour of the noble military art, with his servant a minister, both masked were those who cut the thread of his Majesties life and in it his loyal subjects' happiness' ${ }^{1}$ This article sets out to establish the true background, identify and rise to military command of this mysterious colonel, and then set the significance of his wartime activities into their local political context.

In the torrent of gossip and speculation that followed the regicide, the rumours about Colonel Fox grew to such length that Henry Walker printed in his 'Perfect Occurrences' on 9 February:

Some malicious malignants, out of envy to an honest colonel because he hath been faithful to the Parliament in doing them real service, have reported that he was the King's headsman; who was at that very instant known to be waiting on the lord President; that if any of those reporters of such a base lie were found and taken they will be severely punished. ${ }^{2}$

Of all the enemies of the crown in the British Civil Wars, these royalists singled out John Fox, the governor of the minor, unimpressive parliamentary garrison at Edgbaston House to receive this ultimate notoriety, and in so doing, reveal to us an engaging concern of royalist allegiance.

Both sides sought 'out-groups' upon whom to blame the outbreak of war, and appealed to the people using familiar images that transcended any boundaries between elite and popular culture. While parliamentarians denounced foreign and papist influences, royalist propaganda continually represented the parliamentary forces as 'heretical rebels, led by men of low birth and only 
a selfish morality'. So the royalists' choice of a socially obscure colonel and a renegade minister as the king's executioners is hardly surprising. ${ }^{3}$

John Okey, John Hewson and Thomas Pride are all better known examples than Fox of common tradesmen who attained colonelcies in the parliamentary forces. However, these men were regular soldiers in the New Model Army. They owed their promotions to their Lord General, Sir Thomas Fairfax, who could exercise strict control over their actions. John Fox frightened royalists more as they believed he owed his position to no one:

The rebels intending a reformation by the sword will square their church according to their army. And therefore they thrust all trades into the pulpit since their shops were emptied for colonels and captains. Particularly one Fox, a tinker of Walsall, in Staffordshire, having got a horse and his hammer for a poleaxe, ${ }^{4}$ invited to his society 16 men of his brethren (above half as many as departed this world at Banbury Assize). This jovial Colonel Tinker with his 16 sweet brethren marched seven miles to Birmingham in Warwickshire near which town they fortified a house called Edgbaston House. But (remembering their trade) they pulled down the church to make their fortifications, and disposed of the bells to their fellows of Birmingham. In this house they have nestled so long that their 16 are swollen up to 200 , which rob and pillage very sufficiently.

The royalist image of Fox as a leader of a riot, a tinker, criminal and apostate, was that of an outsider to settled society, a malign danger to the order, unity and stability so universally desired. By scorning Fox as 'the Jovial Tinker', they were presenting an established image of a social subversive that had existed in ballads since at least $1616 .^{6}$

This royalist depiction of Fox as a Walsall tinker has been astonishingly durable. Even Christopher Hill has accepted their propaganda, describing Fox as 'the low born Tinker Fox of Walsall'. A lack of credible primary evidence detailing Fox's social origins has permitted the confusion to continue. D.R. Guttery refers to Fox as 'a Tamworth tinker that set himself up as a soldier', and cannot even get his name right, calling him 'Colonel Thomas Fox'. ${ }^{7} \mathrm{He}$ is confused with the M.P. for Tamworth in 1659 and 1660 in other works, even though by this time Fox had been dead for nine years. ${ }^{8}$

In addition to basing their evaluation of Fox's background on propaganda and assumption, historians, most notably J.W. Willis Bund, have used him to fit their stereotypes of parliamentary soldiers: 'as a specimen of the religious military fanatic he is hard to beat'. Willis Bund continues that Fox was 'one of those men who, by a close study of the Old Testament, brought himself to believe that he was a divinely-selected instrument to carry out the Lord's command on the children of wrath... His surpassing impudence, his insatiable avarice, his cool courage, render him and his troop of horse the typical Roundheads'. If Fox did believe he had been sent by God to crush tyranny, idolatry and to avenge the saints, there is no hint of it in his twelve surviving letters in the Denbigh Manuscripts, in which there is no mention of God or religious issues. ${ }^{9}$ In writing to such a remarkable length about Fox from very few sources, Willis Bund reveals to us much more of his own opinions of the parliamentary cause than John Fox's.

Similarly, in his edition of Dugdale's Diary, William Hamper was eager to claim Fox was illiterate. His evidence was a letter in the Denbigh Manu- 
scripts dated 3 April 1644, in which the word 'Dorpes' is used. He argues this is German for villages, and is therefore evidence that Fox had a German secretary. This may be true, although the clerk for Edgbaston House in the muster roll a year later is John Carter - hardly a German-sounding name. ${ }^{10}$ Hamper then claims Fox signs in an 'illiterate manner'. The particular letter that Hamper refers to is in a strikingly different handwriting to the rest of Fox's letters in the Denbigh Manuscripts; this may be because Fox was absent at Coventry at this time answering charges levelled against him by one of his officers - a Lieutenant Mountford. The handwriting in the rest of Fox's letters is uniformly similar, while his signature is too consistent, fluent and elaborate to suggest illiteracy. In fact his signature closely resembles the earl of Essex's, yet nobody would suggest Essex was illiterate. Yet, unsurprisingly, Hamper's diagnosis was readily accepted a century later in J.C. Muddiman's description that Fox 'had been a tinker by trade, and was quite illiterate, so much so that his letters were written for him by a German secretary'."

While it has not been difficult to challenge what has been written about Fox's origins, in the face of a shortage of conclusive evidence it remains extremely arduous to positively establish his social status. It has been plausibly suggested that he was some kind of metal worker or dealer in one of Birmingham's blade mills, and that royalists could easily corrupt this into him being a tinker; Mercurius Britannicus states that Fox must have 'so much metal that Aulicus conceits he must be of a brazen or copper profession'. ${ }^{12}$ However, Mercurius Aulicus was at least correct in asserting that he was from Walsall. On 1 April 1610, a John, son of Renold Fox was baptised in Walsall parish church, and on 24 June 1634, he married Emme Tudman. ${ }^{13}$ As we shall see, Colonel Fox had a brother named Rheinold or Reighnold, and a brotherin-law named Humphrey Tudman, establishing this John Fox as the later colonel beyond doubt.

John Fox was a soldier before he established the Edgbaston House garrison in October 1643. It is highly likely he had been a captain under Lord Brooke whose campign for support among sub-gentry groups has been described by Ann Hughes as 'rousingly militant'. Captain Edward Foley who had raised and captained a troop of horse for Lord Brooke between 27 January and 1 June 1643, had his service claim certified in 1647 by Colonels William Purefoy and John Fox. ${ }^{14}$ For Fox to be asked to sign such a legal document, he must, like Purefoy, have been involved in Brooke's forces at this early date. A certificate of his accounts as a captain maintaining forty horses dates from 2 July 1643 and claims he was a captain for thirteen months prior to his colonelcy of March 1644. Fox also certified the service of his brother Reighnold Fox as his quartermaster, under a commission from Brooke's successor, the earl of Denbigh, dated 21 June 1643. Reighnold subsequently captained and partly raised a company of foot in the earl of Denbigh's own regiment before joining his brother at Edgbaston as his major. Furthermore, after Brooke was killed at Lichfield on 2 March 1643, his deputy, Sir Edward Peyto sent a Captain Fox to inform Sir John Gell, the parliamentary governor of Derby of the news. ${ }^{15}$

Fox had established the garrison at Edgbaston before 12 October 1643, as 


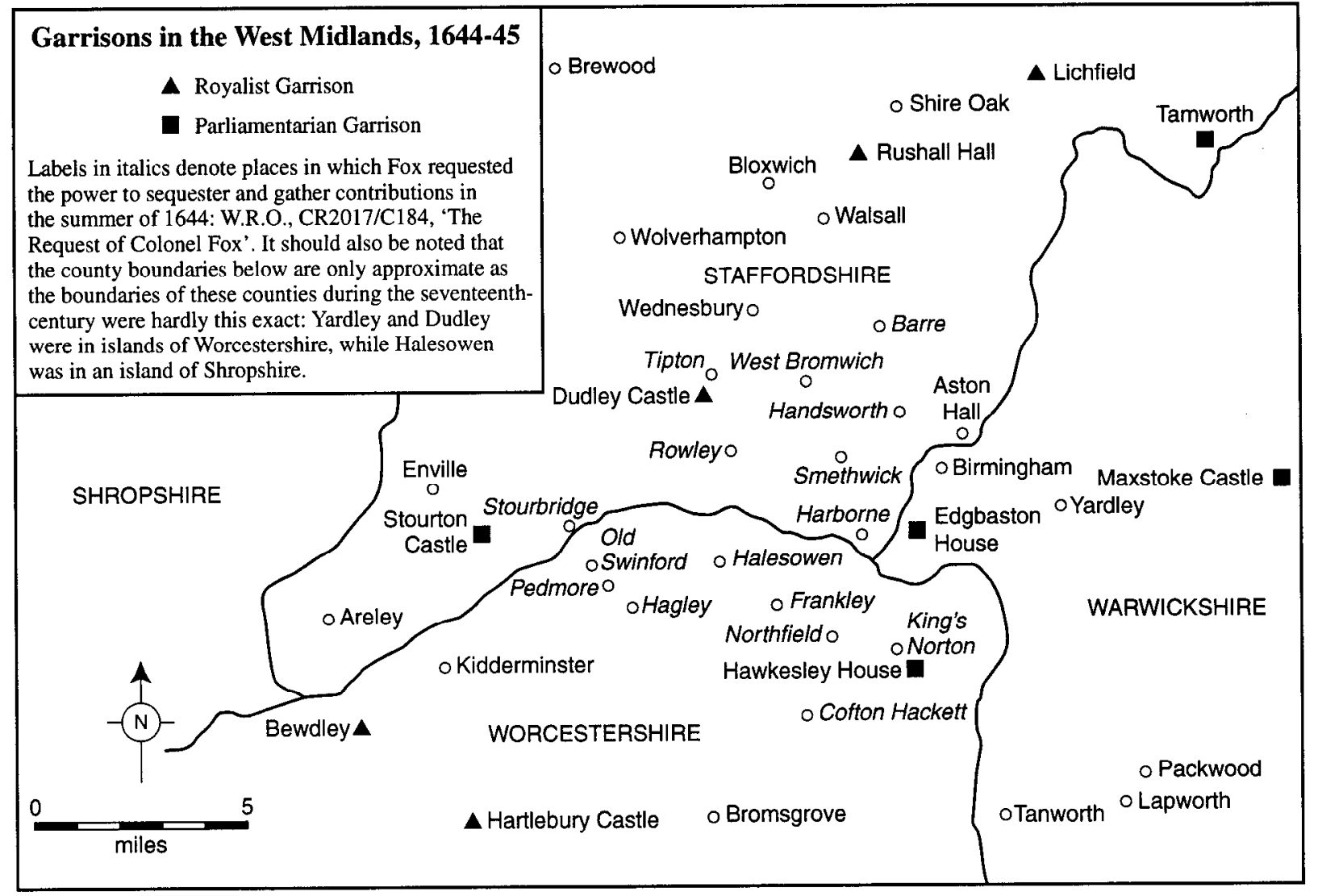

Figure 1. The area of Col. Fox's activity. 
the garrison's accounts begin on this date. It is likely that his men were involved in the storming of Aston Hall on 28 December 1643, thereby removing the closest royalist threat to the survival of Fox's garrison. Edgbaston House was the home of the roman catholic Robert Middlemore, whose recusancy and position among the wealthiest of Warwickshire gentry made his estates a legitimately attainable and attractive base for Fox. Fox's soldiers were certainly active by 22 January 1644, the Committee at Stafford noting at this date: 'To writ to Capte. Fox for the release of two troupers he tooke of Colonel Lane's, for Capte. Gunes sergent and a trouper of Colo. Brownes which are at Rushall Hall'. ${ }^{16}$

Fox brought with him a core of soldiers who had also served in Brooke's army when he came to Edgbaston. With the populous town of Birmingham nearby, he could expect impressive recruitment. Birmingham men were instrumental in denying the king entrance to Coventry in 1642, and because of their resistance their town was plundered and burned by Prince Rupert on 3 April 1643. One of the local blade mills so destroyed was owned by Robert Porter. A man alleged to have supplied fifteen thousand swords to parliament, Porter became Fox's treasurer at the inception of the garrison. ${ }^{17}$ In the years before the war, Godly lectures had flourished in Birmingham and the earl of Clarendon described Birmingham 'as a town so generally wicked that it had risen upon small parties of the King's and killed or taken them prisoners and sent them to Coventry, declaring a more peremptory malice to his majesty than any other place'. Notwithstanding Clarendon's prejudice against such emerging urban centres, it remains that Birmingham was likely to have been a fertile recruiting ground for Fox; Christopher Hill commenting that Fox 'raised a troop among the small craftsmen of the Birmingham district'. ${ }^{18} \mathrm{M}$. Rowlands has argued that by the 1660s around 61 per cent of Birmingham and the Black Country districts' population were such tradesmen and craftsmen, involved in metal working. Furthermore, Ann Hughes has pointed out the conspicuous nature of support for parliament among such sub-gentry groups in north Warwickshire. By 1644, the royal forces were reduced to impressment to raise men along the edges of this region, and the royalist Edward Broade threatened to hang countrymen near Kidderminster if they would not join his regiment. Acts such as this were not going to stimulate royalist sympathy, but in any case Fox took no chances, ordering villagers to remain indoors when the royalists attempted impressment, even taking disobedient villagers prisoner. ${ }^{19}$

Willis Bund's description of Fox's men as 'wild fanatics' and 'unmitigated scoundrels' ${ }^{20}$ does not advance our understanding of who they actually were beyond the diagnosis of Mercurius Aulicus. However, a fair amount of detail can be reconstructed about the men who were to form Fox's regiment. Fox received a colonel's commission from Denbigh in March 1644, to command a regiment to consist of six troops of horse and two companies of dragoons. In June 1644, Fox mustered twenty-five junior officers, 256 horse, dragoons and scouts at Edgbaston, only seventy-four of which were fully armed and mounted. A list of the regiment the following month indicates three troops of horse commanded by Colonel John Fox, Major Reighnold Fox and Captain 
Humphrey Tudman, along with two companies of dragoons under Captains Williams and Johnson. As the garrison shrank in 1645, Tudman remained as the commisary of arms. Tudman was the uncle of Fox's children; he paid Ship Money in Walsall in 1636 and was a trained bandsman for Walsall borough in 1640. Captain John Johnson later commanded a party of twenty-six foot soldiers in the garrison on the muster of 25 April 1645. In 1651, he joined Tudman in distraining the goods of Middlemore's tenants in view of the pay arrears still owed to them as army officers. By this time he was working as an excise collector in Staffordshire. In 1645, John Allen was the CaptainLieutenant to Colonel Fox's own troop, and he may have been the trooper listed six months before serving under one of Denbigh's officers, Colonel Lewis Chadwick, and promoted, perhaps by Fox to a commission. ${ }^{21}$

Pressed by financial anxieties in the summer of 1644, Fox requested Denbigh send him a treasurer, and on 12 July 1645, Thomas Shaw is listed as such. Shaw had been the 'High Collector' for the assessments for parliamentary subsidies raised for the relief of the royal army in the north in 1641 . Shaw had been responsible for Halfshire Hundred, which included parishes like Northfield, Pedmore, Stourbridge, King's Norton, Hagley, Frankley, Dudley, Droitwich and Kidderminster. All of these were parishes in which Fox was later to be active. Shaw's insider knowledge of tax gathering in these areas must have proved very useful to Fox. Like Captain Johnson, he later became an excise gatherer for Staffordshire. ${ }^{22}$

Fox also recruited local men from Edgbaston, such as his quartermaster, Richard Burbige, who between 1639 and 1641 had two of his sons baptised and a widowed relative buried in the parish church. Also serving in Colonel Fox's own troop in 1645 was John Burbige, perhaps another relation. Quartermaster Burbige achieved his moment of fame when the Parliament Scoute reported his defence of Birmingham from the royalist Colonel John Lane on 23 May $1644 .{ }^{23}$ The Hadley family, also of Edgbaston parish provided Fox with soldiers. Thomas and Michael Hadley, are listed as horse shoers among the nine garrison officers at Edgbaston in 1645. The Smallwood family did likewise, John and Thomas Smallwood serving in the Colonel's own troop in 1645. The Hadley and Smallwood families had been linked by a marriage less than two years before the outbreak of war. ${ }^{24}$ William Smallwood, probably John's father, joined Humphrey Tudman and William Fox in begging parliament to make provision for the dead Colonel's children in $1652 .{ }^{25}$ Walter Brooks, a married trooper, fathered four children in the parish. ${ }^{26}$ Another trooper, Jacob Shatwell may have also been a local butcher or farmer for he is frequently paid for provision of meat to the garrison. ${ }^{27}$ The porter of Edgbaston garrison was probably the local man George Green, buried in the parish church in $1663 .^{28}$

Garrison forces such as Fox's comprised a sizeable proportion of all the men under arms in the British Civil Wars. Charles Carlton asserts that in June 1645,48 per cent of all royalist troops served in garrisons, while he notes that one contemporary that spring listed seventy-five garrisons in the midlands and Wales. A garrison's objective was to dominate and control the locality, and so to suppress the enemy by harassing their sympathizers, ambushing their 
patrols and raiding their quarters. Rarely properly paid or provisioned, these forces understandably spent more time gathering maintenance for themselves, than fighting the enemy. In areas where a garrison's control was undisputed, it could ensure military protection to local districts that regularly contributed to its maintenance, but as garrisons came into increased competition for reduced resources, raiding and extortion could become horrific for the local civilian population. Disputes, inflamed by fractured and contested command structures, grew between garrison commanders on the same side in conflict over the collection of money and provisions. ${ }^{29}$

So if Fox's men were the undisciplined ruffians and highwaymen referred to by Willis Bund and others, it was because they were never properly paid. The knowledge that the nearby forces of the Warwick County Committee were regularly paid must have irritated them further. ${ }^{30}$ Because Fox held his colonelcy from Denbigh, whom the County Committee distrusted, they were not interested in funding his troops, while Denbigh himself failed to deliver any financial support. ${ }^{31}$ For the first six months of the garrison's life, whatever pay they received was dependent upon how much they could illegally force local parishes to contribute. It was not until 11 June 1644, that parliament actually granted Fox a formal income: 'Col. Fox is hereby empowered to hold and enjoy the mansion house and manor of Edgbaston, together with the rents and revenues payable to Richard Middlemore in the parishes of Kings Norton, Yardley, and Northfield, in co. Worcester, upon account towards the maintenance of the garrison' ${ }^{32}$ On 22 January 1645, the County Committee at Stafford finally granted Fox the right to collect assessments in the parish of Areley, noting that 'the said colonel or his officers shall have power to demand levy and raise within the said parish of Areley the sum of 66li 17s being three months arrear of their weekly pay at 6li 10 s per week' ${ }^{33}$ Demands of assessment arrears in such large sums as this were unlikely to find the contributors in any position to pay the full amount, and were in any case a piecemeal measure as far as Fox was concerned; these three months of arrears in this parish would not even he enough to pay his garrison for a single week.

Furthermore, when Fox endeavoured to secure funds upon his own enterprise, he was consistently frustrated by Denbigh. On 10 June 1644, Denbigh forbade him to implement his plan to sequester the lordship of Pedmore because it was held by Sir William Boughton, one of Denbigh's kinsmen. ${ }^{34}$ Furthermore, on 15 March Fox complained to Denbigh that the earl's officers encroached upon the areas in which Fox had tried to generate revenue for his garrison through protection rackets:

...issuing forth warrants in your Lordship's name for money to such places as are obedient to my suppositions and are promised protection from me (a copy of one whereof is enclosed) taking of horses from others that have lent horses to me and by me protected...and in special they took a mare from one Mr. Gerande of Middleton Hall in Nor[th]field Parish...protected by me especially though he be a gentleman yet but of small estate and not in action upon the other side, yet he being gracious with some at Worcester and loving to his neighbours hath been the chief safeguard of our friends thereabouts by saving of their goods and regaining what they had lost which was the reason by the mediation of our friends that I did protect him which hath not been in vain nor will unless such congress provide him to that which other ways he would not. ${ }^{35}$ 
Not only were Denbigh's men drawing contributions in areas very close to Edgbaston House, they were also plundering Fox's allies. An officer in Denbigh's own cavalry regiment was still doing this three weeks later, and Fox lost patience with the earl:

Captain Acock in your Lordship's name commanded all the assignations round about us to pay to him, which hath not been by me countermanded, which if I should have done the like (as hitherto I have for borne until I knew your Lordship's pleasure) the country will be in sure distraction as they will exclaim upon both sides for there is an absolute necessity for the one of us to forbear. And if your Lordship command me to forbear then your lordship commands me to destroy this garrison. ${ }^{36}$

With Fox's soldiers left to pay and sustain themselves, they improvised as well as they could. They were frequently reported enjoying free quarter in the north Warwickshire villages of Tanworth, Packwood and Lapworth, and parish records display their indulgence in their own form of property blackmail at Studley: 'Colonel Foxe's men deceitfully caused us to give unto them to save our house from plundering 11s'. When Colonel Fox ordered parts of Edgbaston Church pulled down to provide materials for the fortification of the House, there were probably considerable looting opportunities for his soldiers; the parishioners later claimed five hundred pounds to rectify the 'sustained losses and damages by the destroying of our Church...by those who were under the government of Colonel Fox'. His troopers would also keep strict watch on the roads to harrass any merchants heading towards royalist quarters. The ironmonger Henry Finch of Dudley was captured in this way and detained by Fox at Birmingham, while Fox's men seized the goods of Robert Barrett and John Clownham who were caught on their way to royalist Bewdley. ${ }^{37}$

During the summer of 1644 , Fox compiled a series of proposals to Denbigh to improve his position. He requested the power to sequester 'papist and delinquent' estates, a treasurer from Denbigh and assignations from twentytwo Worcestershire and Staffordshire parishes amounting to $£ 391$ 10s per month. He claimed his forces were increasing daily and requested proper maintenance for them 'till he plant them further upon the enemy's quarters safely'. He also proposed that Denbigh should reinforce him at Edgbaston to enable him to 'march strong into that malignant countey and disarm it, and so awe them into making their contribution duly'. From the inception of his garrison, Fox had little choice but to adopt the strategy of making civilians in cnemy controlled areas pay as much as possible to supply his troops. In his petition to the Lord Protector in 1654, Captain Tudman explained that Fox had maintained the garrison 'by such means as he from time to time drew out of the bowels of the enemy'. ${ }^{38}$

One way in which Fox's regiment could legitimise their existence was as scouts and intelligence gatherers. On 18 March 1644, Fox gave Denbigh a very detailed account of the state of Prince Rupert's forces at their rendezvous at Bloxwich and correctly predicted: 'its credibly thought they are bound for Newark'. On 3 April, Fox demonstrated his expertise again informing Denbigh of Rupert's quarters around Shire Oak and Hampton Brewood: 'We hear his 
soldiers talk of Stafford and some other garrisons of ours as though they would besiege them. But we know designs are kept more secret: This day's march will discover certainly which way he bends, whereof I have taken course to have certain intelligence'. On 8 July, Fox passed more information to Denbigh on the whereabouts of the king himself. ${ }^{39}$ The following June, he informed Sir Samuel Luke, the parliamentary governor of Newport Pagnell of a defeat inflicted only the day before by the forces of Shrewsbury upon the royalist governors of Monmouth, Hereford, Worcester and Ludlow who had united into one field force. The speed of Fox's intelligence networks show how effective his systems were. Fox received a letter containing intelligence of the king's army's movements written after 10 p.m. on 10 May 1645, at either Alcester or Evesham, Fox had ensured its delivery along with his letter to Sir William Brereton written after midnight to the parliamentary garrison at Stafford, leaving time for them to despatch it with their letter to Brereton by 9 a.m. on 11 May. The intelligence had travelled a distance of up to sixty miles overnight; it is quite probable that Fox had established a network of safe houses and fresh horses for his scouts to enable these missions to succeed. In true enterprise spirit, Fox had requested to Denbigh the year before that such intelligence should be rewarded. ${ }^{40}$

The constant energy and vigilance displayed by Fox's regiment probably arose more from necessity than enthusiasm. When plunder, provision and accumulation of prisoners for ransom or exchange were the foremost requirements to maintain Fox's garrison, his troopers would need to be active surprising and 'beating up' enemy quarters. Simon Osborne has commented that the 'juxtaposition of so many garrisons in the region resulted in a process of raid and counter-raid that lasted for much of the war'. Fox sent out such a raiding party under Captain Tudman to fall on enemy quarters near Hartlebury castle, where they captured a Sergeant Whittlewerk and four prisoners. At about the same time a party was sent out under Captain Johnson to 'secure' the fair at Atherton, where they clashed with royalist troopers under Colonel Lane probably there for the same reason. The London press claimed that Colonel Lane had been mortally wounded in this encounter, and that Fox's troopers took his horse, pistols, beaver hat and cloak. ${ }^{41}$ On another occasion, while Colonel Fox was in London at the end of May 1644, Captains Reighnold Fox and John Johnson led sixty horse to surprise and beat up the royalist quarters at Bromsgrove, causing 'some of them to fly without their horses, some without their clothes, in a great distraction'. In December 1644, Fox demonstrated the speed of his intelligence networks and his astute opportunism in the raiding of Dudley only hours after most of the royalist garrison had been marched out:

The Duke stayed not at Dudly but went forward to Stirbridge by which means we scaped Foxe's alarum, who the same night fell into Dudly, where he took some horses, amongst which Commissary Warde had two. Himself escaped but they released six and twenty of the prisoners which were in the church, no guard being kept in the town nor much I fear in the castle, for they said they had not forty men left but all gone out with the Colonel, horse and foot. ${ }^{42}$ 
Without the necessary money and manpower, Fox could never hope to hold the enemy quarters or garrisons he raided, so he developed systems of looting that would yield the finest prizes in the shortest time. Entered in Dugdale's diary on 3 May 1644, Fox's raid on Bewdley vividly illustrates this, his preferred style of garrison warfare. With a party of sixty of his best troopers he bluffed his way into Bewdley, allegedly pretending to be a troop of Prince Ruper's horse that had lost their way. He took forty prisoners, forty horses and plucked the royalist governor, Sir Thomas Littleton of Frankley, out of his bed in Ticknell House. ${ }^{43}$ Shaking off his pursuers, he safely arrived in Coventry with his prizes. ${ }^{44}$ Such deeds did not go unnoticed in London and in its praise of Fox, one London newsbook exclaimed: 'It were to be wished that all our commanders would thus lend themselves to continual motion and action, and content themselves to perform what duty they can, within the limits of their own power, and be ready to assist each other: That so the Kingdome might move as one body against the common Enemy. This would shorten the Business'. ${ }^{45}$

However, Fox's 'continual motion and action' was more of a necessity for the survival of his garrison, than a deliberate war winning strategy; even had he desired it, he was certainly in no position to assist other commanders or satisfy London propaganda. Fox had problems of his own at Edgbaston, writing to Denbigh on 15 April: 'Could my Lord think of my condition, my soldiers run away apace and were this day upon training ready to lay all their armes down and depart'. Ten days earlier he wrote an ominous, if alarmist letter to Denbigh:

The extreme want of money not only to pay my soldiers but to buy victuals for the house, and hay and oats for the horse is such we having taken upon credit as far as our credits will extend, And indeed...I could not wait upon your Lordship upon this weighty occasion for fear of a mutiny and a general departure of my soldiers (whose of many have of late been guilty) for want of necessaries for their necessary subsistence....And yet there be not a speedy course for money, which for a long time my soldiers have been promised and served a hopeful expectation which failing I need not enemies to destroy us for this garrison will destroy itself. ${ }^{46}$

The one time in 1644 when Fox attempted something more ambitious than a raiding party, the support he received from his colleagues and superiors was negligible. Dugdale recorded that on 22 March: 'This night... brother to Fox the Tinker ${ }^{47}$ (which keeps a garrison of Rebels in Edgbaston house com. Warr.) entered Sturton Castle com. Stafford, with 200 men... to plant a garrison there'. Stourton had more than twenty smithies on the banks of the River Stour and the Smesthall stream, all of which had been supplying the king with munitions. On 24 March, Fox pointed out to Denbigh its strategic importance, requesting reinforcements, or at least to return to him Reighnold Fox and his troop: 'Your Captains like it very well for situation and strength it being on the road that leads from Worcester to Bridgnorth, and from Worcester to Dudley and in the midst of the enemy's quarters so as they apprehend them secure and are if this garrison be not removed, which will be out of their power if your lordship have a care there of.$^{48}$ Located in the heart of a network of royalist quarters, a parliamentary garrison at Stourton would enable Fox to disrupt 
their communications, collect their contributions and plunder the civilian population that maintained them. Despite one of the earl's officers, Humphrey Mackworth, urging Denbigh that 'there might be a special care had of this garrison', no help from Denbigh arrived. As Fox expected, only three days later, the royalist garrison of Worcester under Sir Gilbert Gerard were marching out to recapture Stourton. With only 110 foot from Coventry in addition to his Edgbaston forces, Fox advanced to meet them. He next wrote to Denbigh on 27 March, describing how his forces had been routed and reminded him of his failure to provide support: '...our humble desire is that some speedy course may be thought upon to help us with more strength being great pity to lose such a place.' ${ }^{49}$ Mercurius Auficus celebrated the superior breeding of the royalists in their victory over Fox:

The first running rebel was the Jovial Tinker himself, whose example was well followed by all his worthy trayne. The rebels in the castle sccing Tinker Fox so piteously bang'd, desired liberty to march away, and they would resign the Castle; Sir Gilbert considering that the chief man among them was Colonel Tinker's brother-in-law, conceived them unworthy the charge of a guard, therefore he bid them lay down their arms and go whither they pleased..$^{50}$

Against his better judgement, Fox felt he had been forced to fight an open field action by Denbigh's inactivity. It is unlikely he ever did so again. He was not present with Denbigh at the Battle of Tipton Green, ${ }^{51}$ and when Denbigh ordered Fox to send $\mathbf{1 5 0}$ foot to Colonel Thomas Archer at Camden, Fox made his point, supplying Archer 'only with 60 and those unarmed, who being altogether unserviceable were returned again'. When Denbigh ordered that a royalist gentleman prisoner in Fox's custody be exchanged for a Mr. Wakefield, instead of Fox's soldiers captured at the fight ouside Stourton, Fox's reply could not conceal his frustration. He informed Denbigh that the prisoner in question had already tried to kill him once, was not fit to be released, and even if he were Denbigh's choice was an unwise exchange, especially when 'there is great case to be made of him for the exchange of ours in prison would think it strange that other prisoners should be released by him and they lie for want of exchanges, which he will solve of many, especially they being most wounded men and stand in need of present enlargement'.52 The royalist gentleman by virtue of his status would be worth the exchange of several of Fox's common soldiers and it is easy to understand Fox's exaspertion at being told to explain to his soldiers that their prisoner was not going to be exchanged for their comrades at all, but for a gentleman favoured by the earl of Denbigh.

Ann Hughes has pointed out that Denbigh 'consistently supported the view...that the civil war should not be allowed to undermine the social hierarchy'. He also knew that to the royalists, Fox was a criminal who would respect neither status nor hierarchy. Realising that because of his reputation he would never be fully supported by Denbigh, Fox took initiatives of his own to enhance his position, in direct opposition to the earl. Denbigh's secretary, William Crowne wrote to him from London on 16 July 1644, that he had been notified of an ordinance raised by a 'Mr. Geust' and some friends of Colonel Fox that would limit the earl's power by giving to a committee of six the power 
to appoint commanders and to raise money in Worcestershire. On 23 September, Fox headed the list of army officers appointed to the Committee of Worcester. Although the royalists still controlled most of Worcestershire, the committee was endowed with potentially considerable powers and was to sit at Fox's newly established garrison at Hawkesley House. When Sir William Brereton and Sir John Gell, suspicious of Denbigh, removed his Colonels Chadwick and Rugeley from the governorship of Stafford in December 1644, it is interesting to note that they made no such move against Fox. ${ }^{53}$

Although there is no sign of Fox supporting Denbigh in 1645, neither did he receive encouragement from Denbigh's rivals, the Warwick County Committee headed by William Purefoy at Coventry. They complained of the misdemeanours of his unruly soldiers and resented their inability to command him. They quarrelled with Fox over the rate allowed for the maintenance of his horses at Edgbaston, and despite the muster rolls agreeing perfectly with the demands made in Fox's accounts, the committee entertained rumours that false musters were made at Edgbaston. They then accused Fox and his men of withholding three thousand pounds worth of plunder taken from Sherrington Talbot and Sir Thomas Litleton, while claiming that Fox was personally between three and four hundred pounds in debt to the state. They later sided with Robert Porter in his struggle with Fox over the rents of Edgbaston House, accusing Fox of embezzlement and deceit over arrears of pay. Thomas Dudley, a quartermaster in the Edgbaston garrison and the treasurer Thomas Shaw both agreed that the committee never made a true account of their colonel's service. With the committee stretched to pay its own troops it was not about to settle the expenses of a colonel outside their establishment, especially one with such a controversial reputation. ${ }^{54}$

In the months leading up to his death in 1650 , Fox was in great debt, in a state of sickness and described in the proceedings of the Council of State as 'being ready to starve.' Financially ruined by his wartime activism, he left his children impoverished. Despite claiming to be almost ruined by the loss of his stock and trade in parliament's service, and 'left without hope of his arrears', Humphrey Tudman charitably maintained these children for three years. He petitioned the Committee for Compounding with Delinquents in 1653 'for supply of their great wants, lest otherwise the Commonwealth's enemies say in reproach - and especially in the country where his service was so eminent, - "These are the children of Colonel Fox." ' When this petition failed, William Fox and William Smallwood warned the committee that Tudman 'doth affirm he will send the said children to beg for their livings.' Tudman was probably right that Fox had few friends in the counties where he fought. Endeavouring to maintain a regiment of soldiers with pitiful financial support had hardly courted popularity. Fox provides us with a striking paradigm of a minor military entrepreneur without the status, reputation or resurces required to prevent his ultimate ruin. He cannot be inserted into Mosler's dichotomy of upper gentry moderates supporting Denbigh led by Sir Simon Archer clashing with the Warwick County Committee's lesser gentry radicals led by William Purefoy. Carlton comments that garrison commanders frequently experienced 'a sense of being disowned, rather than 
having been given an independent command', but Fox was even more isolated than most. Rejected by both Denbigh and the County Committee, Fox's reputation forced him down a path of independence. Like Fox, the County Committee may have been both locally minded and militant, but it neglected to fund him, accused him of corruption and even confiscated his rents at Edgbaston. $^{55}$

There were other low born officers in the nearby forces of the Warwick County Committee. The Coventry butcher, Thomas Hobson was a lieutenant of foot in the county regiment. Lieutenant Goodere Hunt, Governor of Astley House was an illiterate shoemaker before the war. He was prosecuted in 1647 for requisitioning a gentleman's horse; Ann Hughes points out that 'gentlemen were not accustomed to being ordered to relinquish their property in this fashion' ${ }^{56}$ The names of Wat Tyler, Jack Cade and Robert Kett, now linked to a new religious radicalism, once more haunted a fearful gentry. As early as June 1643, one royalist newsbook sneered that rebel towns were governed by tinkers, cobblers and pedlars, who 'usually preach (for preach they do) to their infatuated disciples, and by them are received as the divine oracles of God' ${ }^{57}$ For many of his enemies, Fox came to embody this perceived link between lower-class activism and religious radicalism. His high rank of colonel, his relative independence and lack of an effective superior officer which left him potentially unchecked, rendered him still more dangerous to them. No wonder Robert Middlemore offered the royalists a large sum of money to recapture Edgbaston House. His desecration and demolition of the heraldic monuments of the Middlemores in Edgbaston parish church intensified such anxieties of him among the gentry community as a whole. Much of that community would have felt it disturbingly fitting that who they saw as the leader of a riot of Birmingham and Black County smiths should be commanding the Lord President's guard at the trial and execution of Charles I. Fox had acquired a political significance that far outweighed his military one. During the king's trial, he was arrested for debt and thrown into prison, having to be released by a special order of the court. ${ }^{58}$ If there ever was a 'County Community' in Warwickshire during or even before the Civil Wars then John Fox was never part of it. Politically as well as geographically, 'Tinker' Fox stood on the margins of the county.

\section{NOTES}

1 I would like to thank Prof. J.A. Sharpe, Dr. J.S. Morrill, Dr. M.S.R. Jenner and Dr. A.J. Warren for their useful criticisms arising from reading this essay. I also thank Professor A. Hughes for her kind permission to quote from her Ph.D. thesis and Ms. M. Dodkins for the reference from Walsall parish registers. G. Dyfnallt Owen (ed.), Report on the Manuscripts of the Right Honourable Viscount De L'Isle, Sidney Papers, 1626-1698 (Hist. Man. Com., LXXVII, 1966), VI, 583; J.C. Muddiman (ed.), The Trial of King Charles the First (London, 1928), 148n.

2 Muddiman (ed.), The Trial of Xing Charles the First, 167-8.

3 K. Sharpe and P. Lake (eds.), Culture and Pofitics in Early Stuart England (Basingstoke, 1994), 11; J. Raymond (ed.), Mafing the News: An Antfology of the Newsbooks of Revolutionary England, 1641-1660 (Moreton-in-Marsh, 1993), 84.

4 Mercurius Auficus quickly made the connection between this area's abundance of smithies, mills and metalworks with Fox as an itinerant tinker of the area.

5 P.W. Thomas (ed.), The English Revolution III, Reus6ooks I, Oxford Royatist (London, 1971), 
II, 839; Mercurius Auficus, 18 February 1643(4).

6 N. Wurzbach, The Rise of the Engfish Street Ballad, 1550-1650 (Cambridge, 1990), 328; C.M. Simpson, The British Broadside Ballad and Its Music (New Jersey, 1966), 713.

7 C. Hill, The Century of Revolution: 1603-1714 (2nd edn., London, 1980), 107; D.R. Guttery, The Great Civil War in the Midland Parishes, The People Pay (Birmingham, 1951), 9, 67.

8 R.M. Kidson (ed.), 'Active Parliamentarians during the Civil Wars', Wiffiam Salt Arch. Soc., 4th ser., II (1958), 16; D.H. Pennington and I.A. Roots (eds.), The Committee at Stafford, 16431645: The Order Book of the Staffordshire County Committee (Manchester, 1957), 40n., 369, in which he is also indexed as Colonel Thomas Fox. For Fox's death between 21 October and 9 November 1650, see M.A.E. Green (ed.), Calendar of State Papers Domestic, 1650 (Reprint edn., London, 1965), 395, 423; M.A.E. Green (ed.), Calendar of the Committee for Compounding with Definquents (Domestic), 1643-1660 (London, 1889), 2367.

9 J.W. Willis Bund, 'A Civil War Parliament Soldier: Tinker Fox', Reports and Papers Read at the Meetings of the Architectural Soc., Worcs. Archaeological Soc (1918), 403; J.W. Willis Bund, The Civil War in Worcestersfire, 1642-1646; and the Scotch Invasion of 1651 (London, 1905), 30-1; Warwickshire Record Office (hereafter W.R.O.), CR2017.

10 W. Hamper (cd.), The Life, Diary and Correspondence of Sir William Dugdale, with an appendix (London, 1827), 66n; Public Record Office (hereafter P.R.O.), S.P. 28/122 part ii, fo. 272.

"1 W.R.O., CR2017/C9-76; CR2017/C9-80; Muddiman (ed.), The Trial of King Chatles the Fitst, 73.

${ }^{12}$ C.S. Jannes (ed.), The Registers of Edgbaston Parish Church, 1636-1812. vol. i, (Publications of the Dugdale Soc., VIII, 1928); Willis Bund, 'A Civil War Parliament Soldier: Tinker Fox', 380; F. Willmore, $A$ History of Walsall (1877), 314.

${ }^{13}$ Staffordshire Record Office, transcripts of the parish registers of St. Matthew's parish church, Walsall.

${ }_{14}$ P.R.O., S.P. 28/182; A. Hughes, 'Warwickshire on the Eve of the Civil War: A County Community?', MidL. Yist., VII (1982), 63; P.R.O., S.P. 28/253a, i, fo.26.

15 P.R.O., S.P. 23/85/392-4,399; W.D. Hamilton (ed.), Calendar of State Papers Domestic, 16451647 (London, 1891), 274; A. Polkey, The Civil War in the Trent Valley (Derby, 1992), 13. Given Denbigh's concern to establish men of status as officers in contrast to the Warwick County Committee this might suggest the Foxes had more respectable origins.

${ }^{16}$ P.R.O., S.P. 28/182; Hamper (ed.), The Life, Diary and Correspondence of Sir Wilfiam Dugdale, 57; Hughes, 'Warwickshire on the Eve of the Civil War: A County Community?' 51; Pennington and Roots (eds.), The Comnittee at Stafford, 40.

${ }^{17}$ Hughes, Politics, Society and Civil War in Wartwickshire, 9, 147; V.C.H. Warwicks., VII, 84, 271; P.R.O., S.P. 28/182. Ann Hughes reckons the population around this time to be five thousand.

${ }^{18}$ Hughes, 'Warwickshire on the Eve of the Civil War: A County Community?', 51; Hughes, Politics, Society and Civil War in Waruicksfire, 149; W.D. Macray (ed.), The Great Rebelliom, 6 vols (Oxford, 1888), II, 359; Hill, Century of Revolution, 107.

${ }^{19}$ Hughes. Politics, Society and Civil War in Waruicksfire, 8, and passim; M. Rowlands, Masters and Men: The West Midlands Metaluare Trade before the Industrial Revolution (Manchester, 1975), 21; M. Atkin, The Civil War in Worcestersfire (Stroud, 1995), 67, 150; S. Osborne, 'The War, the People and the Absence of the Clubmen in the Midlands, 1642-1646', MidL Hist., XIX (1994), 97.

${ }^{20}$ Willis Bund, The Civil War in Worcestersfire, 1642-1646, 30, 120.

${ }^{21}$ W.R.O., CR2017/C9-54; A. Hughes, 'Politics, Society and Civil War in Warwickshire, 162050 ' (University of Liverpool, Ph.D. thesis, 1979), 513; P.R.O., S.P. 28/122, ii, fo.272; G.P. Mander (ed.), 'The Walsall Ship Money Papers, 1635-36', Wilfiam Saft Arch. Soc (1931), 113; G. Wrottesley, 'The Staffordshire Muster of 1640', 'Wilfiam Salt Arch. Soc, XV (1894), 213; Green (ed.), Calendar of the Committee for Compounding with Definquents, 2367; Pennington and Roots (eds.), The Committee at Stafford, 231-2.

${ }^{22}$ W.R.O., CR2017/C184; J.W. Willis Bund (ed.), The Diary of Henry Toumshend of Elmley covett, 1640-1663, (Worcs. Hist. Soc., XXXVI, 1915-1917), part ii, 43; Green (ed.), Calendar of the Committee for Compounding with Delinquents, 2367.

${ }^{23}$ P.R.O., S.P. 28/122, ii, fos.272, 276; James (ed.), Registers of Edg6aston Parish Church 2; 
Willmore, $\mathcal{A}$ History of Walsall, 316.

${ }^{24}$ James (ed.), Registers of Edg6aston Parisf Church, 2, 4, 8; P.R.O., S.P. 28/122, ii, fos.272, $275,276$.

${ }^{25}$ Green (ed.), Calendar of the Committee for Compounding with Delinquents, 2368.

${ }^{26}$ P.R.O., S.P. 28/122 part ii, fo.274; S.P. 28/123 part ii, fo.293; James (ed.), Registers of Edgbaston Parish Church, 5, 13.

${ }_{27}$ P.R.O., S.P. $28 / 122$ part ii, fos.272-3; S.P. $28 / 182$.

28 James (ed.), Registers of Edgbaston Parish Church 8; P.R.O., S.P. 28/122, ii, fo.272.

29 C. Carlton, Going to the Wars: The Experience of the British Civil Wars, 1638-51 (London, 1992), 150-54; M. Bennett, " "My Plundered Townes, My Houses Devastation": The Civil War and North Midlands Life, 1642-1646', MidC. Fist, XXII (1997), 43.

${ }^{30}$ Hughes, Politics, Society and Civil War in Warticksfire, 187.

${ }^{31}$ For a discussion of the conflict between Denbigh and the Warwick County Committee see D.F. Mosler, 'The "Other Civil War": Intemecine Politics in the Warwickshire County Committees, 1642-1659', Midl. Hist., VI (1981), passim; while for Denbigh's financial weakness see Hughes, Politics, Society and Civil War in Warwickshire, 229-30.

${ }^{32}$ W.D. Hamilton (ed.), Calendar of State Papers Domestic, 1644 (London, 1888), 222.

${ }^{33}$ Pennington and Roots (eds.), The Committee at Stafford, 244.

${ }^{34}$ W.R.O., CR2017/C9-122.

35 I6id., C9-58.

36 I6id., C9-76A.

${ }^{37}$ P. Tennant, Edgefill and Beyond: The People's War in the South Midlands, 1642-1645 (Banbury Hist. Soc., XXIII, 1992), 217, 230; S.C. Lomas (ed.), Report on the Manuscripts of the Earl of Denbigh (Hist. Man. Com., LXVIII, 1911), V, 79; Hamilton (ed.), Calendar of State Papers Domestic, 1645-1647, 332.

38 W.R.O., CR2017/C184; Green (ed.), Calendar of the Committee for Compounding with Definquents, 2368.

${ }^{39}$ W.R.O., CR2017/C9-64; CR2017/C9-76; CR2017/C10-137.

${ }^{40}$ H.G. Tibbut (ed.), The Letter Books of Sir Samuel LuKe, 1644-1645 (London, 1963), 562-3;

R.N. Dore (ed.), The Letter Books of Sir Wiffiam Brereton (Lancs. and Ches. Rec. Soc., CXXIII, 1984), (A82)- 474-6; W.R.O., CR2017/C184.

${ }^{41}$ Osborne, 'The War, the People and the Absence of the Clubmen in the Midlands', 88; British Library Thomason Tract (hereafter B.L. TT), E256(6), Perfect Occurrences of Parliament (London, 1644); P.R. Newman, The Old Service: Royalist Regimental Colonels and the Civil War, 16426 (Manchester, 1993), 274, confirms that Lane was 'severely disfigured' at this time.

${ }^{42}$ B.L. TT E252(40), Perfect Occurrences of Parfiament (London, 1644); F. Bickley (ed.), A Report on the Manuscripts of the late Reginald Rarudon Hastings esq. (Hist. Man. Com., LXXVIII, 1930), II, 134.

${ }^{43}$ Hamper (ed.), The Life, Diary and Correspondence of Sir Wilfiam Dugdale, 66; R. Sherwood, The Civil War in the Midlands, 1642-1651 (2nd edn., Stroud, 1992), 91.

44 For a swashbuckling if poetically licenced account of the Bewdley escapade see Willis Bund,

'A Civil War Parliament Soldier: Tinker Fox', 397-400.

${ }^{45}$ B.L. TT E256(6), Perfect Occurrences of Parliament (London, 1644).

${ }^{46}$ W.R.O., CR2017/C9-81; CR2017/C9-76A.

${ }^{47}$ Probably actually Captain Humphrey Tudman, Fox's brother-in-law.

${ }^{48}$ Hamper (ed.), The Life, Diary and Correspondence of Sir Wilfiam Dugdale, 63-64; Guttery,

The Great Civil War in the Midland Parishes, 68; W.R.O., CR2017/C9-70.

${ }^{49}$ W.R.O., CR2017/C9-70; CR2017/C9-73.

50 B.L. TT E42(26) Mercurius Auficus (Oxford, 1644); Thomas (ed.), The Engfish Revolution III, News6ooks I. Oxford Royafist, ii, 908. Fox informs Denbigh of the surrender of Stourton Castle on 28 March: W.R.O., CR2017/C9-74.

51 Denbigh wrote to Fox on the day of the battle: W.R.O., CR2017/C9-122.

${ }^{52}$ W.R.O., CR2017/C10-26; CR2017/C9-75.

53 A. Hughes, 'Militancy and Localism: Warwickshire Politics and Westminster Politics, 16431647', Trans. of the Royal Hist. Soc, 5th ser., XXXI (1981), 53; Denbigh Manuscripts, C10-13: 
(Hist. Man. Com., IV Rep., 1874), 269; C.H. Firth and R.S. Rait (eds.), Acts and Ordinances of the Interregnum, 1642-1660, 3 vols. (London, 1911), I, 507; for the seat of the Worcestershire Committee as at Hawkesley see Dore (ed.), The Letter Books of Sir Wifliam Breretom, (A121)543; Sherwood, The Civil War in the Midlands, 108-9.

54 Information from A. Hughes in Dore, The Letter Books of Sir Wilfiam Bretetom, (A82)-475n; House of Lords Manuscripts, (Hist. Man. Com., VI rep., 1877), appendix, 188; P.R.O., S.P. 23/ 85/392-6.

55 M.A.E. Green (ed.), Calendar of State Papers Domestic, 1650 (Reprint edn., London, 1965), 260, 395; P.R.O., S.P. 23/85/414-6; Mosler, "The "Other Civil War": Internecine Politics in the Warwickshire County Committees', 63; Carlton, Going to the Wars, 152; House of Lords Manuscripts, (Hist. Man. Com., VI Rep., 1877), appendix, 188.

${ }^{56}$ A. Hughes, 'Parliamentary Tyranny? Indemnity Proceedings and the Impact of the Civil War: A Case Study from Warwickshire', MidL Hist., XI (1986), 58.

${ }^{57}$ D.L. Smith, 'Catholic, Anglican or Puritan? Edward Sackville, Fourth Earl of Dorset and the Ambiguities of Religion in Early Stuart England', Trans. of the Royal Hist. Soc., 6th ser., II (1992), 119; B.L. TT E105(25), Mercurius Rusticus (Oxford, 1643); Hughes, 'Parliamentary Tyranny?' 51, points out that Major George Purefoy was compared to Wat Tyler, while Mercurius Rusticus denounced the parliamentary governor of Chelmsford as a tinker, Colonel Venn as beggarly, and Colonel Long as a Wat Tyler: Thomas (ed.), The English Revolution III, Nezusbooks I, Oxford Royafist, IV, 140, 145, 196, 244.

${ }^{58}$ M.A.E. Green (ed.), Calendar of the Proceedings of the Committee for the Advance of Maney, 1642-1656 (London, 1888), 1110; Tennant, Edgefill and Beyond, 230; J. Raymond (ed.), Making the News: An Anthology of the News6ooks of Revolutionary England, 1641-1660 (Moreton-inMarsh, 1993), 227; C.V. Wedgwood, The Trial of Charles I (London, 1964), 150. 